\title{
Arkadaşlık İlişkilerinde Yaşanan Değişim: Mardin Örneği ${ }^{1}$
}

\author{
DOI: 10.26466/opus.642395
}

*

\author{
Ömer Aytaç * - Mehmet Tan ** \\ * Prof. Dr., Fırat Üniversitesi İnsani ve Sosyal Bilimler Fakültesi, Sosyoloji Bölümü, Elazı̆̆ \\ E-Posta: oaytac@firat.edu.tr ORCID: $\underline{\text { 0000-0002-5435-7107 }}$ \\ ** Arş. Gör. Dr., Siirt Üniversitesi Fen-Edebiyat Fakültesi, Sosyoloji Bölümü, Siirt \\ E-Posta: mehmet.tan@siirt.edu.tr \\ ORCID: 0000-0003-3528-988X
}

\section{Öz}

Arkadaşlık ilişkileri modernleşme, teknolojik gelişme ve küreselleşme gibi etkenlere bağlı olarak değişmektedir. Modern yaşam; rasyonalite, bireyselleşme ve hız parametrelerine dayalı olarak yoğun bir değişim/dönüşüm sarkacı altındadır. Bu doğal olarak her türden ilişki ve etkileşim süreçlerini de etkilemekte, hayatın doğal ve spontane yapısını dönüştürmektedir. Bir asal bağlllık türü olarak arkadaşlık da bu süreçte değişime uğramakta, anlamı ve deneyimlenme formları farklılaşmaktadır.Bu çalışmada, günümüz toplumunda arkadaşlı ilişkilerinde yaşanan değiş̧im odağa alınmakta ve bu değişimde pay sahibi etkenlere ve bunların dönüştürücü gücüne dikkat çekilmektedir. Çalışmada yarı yapılandırılmış görüşme tekniği kullanılarak Mardin'de 40 kişi ile yapılan görüşme verilerinden yararlanılmıştır. Araştırmada öne çıkan bulgular arasında; arkadaşlık ilişkilerinde köklü bir değişim yaşandığı, bunun hemen her kesimde, sosyal sinıfta, cinsiyet ve mesleki gruplarda görülebildiği ifade edilmektedir. Arkadaşlık ilişkilerinde sahici, samimi, diğergam ve güvene dayalı arkadaşlıkların yerini yüzeysel, ikincil, gösteriş̧̧i, bencil ve riskli arkadaşlıklar almaktadır. Ancak bu yöndeki değişimlere rağmen zaman içerisinde arkadaşlı̆̆ın kendisini toplumsal şartlara bağhl olarak yeniden ürettiği ve gücünü ve gerekliliğini muhafaza ettiği görülmüştür.

Anahtar Kelimeler: arkadaşlık,sahici ve samimi arkadaşlık, gösteriş̧̧i ve yüzeysel arkadaşlık, diğergam arkadaşlık, bencil arkadaşlık

\footnotetext{
${ }^{1}$ Bu çalışma, "Arkadaşlığın Sosyolojisi: Değişen Arkadaşlık ilişkileri Üzerine Bir Araştırma (Mardin Örneği)" başlıklı doktora tezinden yararlanılarak hazırlanmıştır.
} 


\title{
Changes In Friendship Relations: The Case Of Mardin
}

\begin{abstract}
Friendship relations change due to factors such as modernization, technological development and globalization. Modern life undergoes intense changing / transformation pendulum based on rationality, individualization and speed parameters. This naturally affects all kinds of relationship and interaction processes and transforms the natural and spontaneous structure of life. In this process, friendship as a prime commitment changes and, its meaning and experience forms differ.This study focuses on the change in friendship relations in today's society and draws attention to the contributing factors and their transformative power in this change. In this regard, interview data with 40 people in Mardin were used by using semi-structured interview technique. As a result of outstanding findings; It is stated that there is a radical change in friendship relations and this can be seen in almost all category, social class, gender and professional groups. In friendship relationships, genuine, sincere, altruism and trust-based friendships are replaced by superficial, secondary, pretentious, selfish and risky friendships. However, in spite of the changes in question, it has been seen that friendship regenerates itself depending on social conditions and maintains its strength and necessity.
\end{abstract}

Keywords: friendship, truly and intimate friendship, pretentious and superficial friendship, altruism friendship, selfish friendship 


\section{Giriş}

Arkadaşlık, kişilerarası bir ilişki türüdür. Sosyal bir varlık olan insan, sosyal çevresinde bulunan insanlar ile sürekli bir etkileşim içerisindedirler. Bazıları bu ilişkileri derinleştirerek dostluk ve arkadaşlıklar kurma yoluna gitmektedirler. Arkadaşlı̆̆ın sosyal yaşam için hayati gerekliliğinin yanı sıra sosyalleşme, topluma katılma, grup kurma, toplumda bir yer, kimlik, statü edinmeye varıncaya kadar sayısız fonksiyonları da bulunmaktadır. Arkadaşlık ilişkileri, gündelik sosyal yaşamın sürdürülmesindeki işlevselliği nedeniyle hemen her zaman, her toplumda varlığına tanık olunan, işlevselliği olan bir sosyal müessese olarak görülmektedir. Özellikle geleneksel toplumlarda arkadaşlık ilişkileri daha muhkem, güvene dayalı, uzun vadeli ve oldukça hayati bir önemdedir.

Modernleşme, kentleşme, endüstrileşme vb. radikal değişim dalgaları, toplumsal yapıları, pek çok yönden sarstığından bildik, alışılagelen işleyiş sistematiği tersine dönmeye başlamıştır. Gündelik yaşamın harcını oluşturan ilişki sistemleri, değer ve norm yapıları, ahlaki ve kültürel kalıplar söz konusu hızlı ve radikal değişimden nasibini almışlardır. Arkadaşlık, akrabalık, komşuluk, ailesel bağlılıklar vs. eski anlam ve değerini kaybetmeye başlamış, zamanın ruhu, teknolojinin gücü, yoğun ve akışkan küresel dinamikler, toplumsallık ve cemaatsel formlar üzerinde parçalanma, yarılma etkisi yaratmaya başlamıştır. Bu çerçeveden bakıldığında, günümüz toplumunda sosyal ağların, topluluksal formların giderek mortialbir çizgiye doğru kaydığı görülmektedir.

Günümüztoplumunda küreselleşmenin artan etkisiyle aile ve diğer sosyal ağlar büyük bir risk altındadır. Aile duygusal harcını kaybettiği gibi, arkadaşlık, grup ve topluluksal yapılar da bireyselleşme ve rasyonalitenin etkisiyle eski güç ve önemlerini yitirmektedirler. Kapitalist toplum kurgusu içerisinde her şey gibi arkadaşlık ve dostluklar da maddi ve karşılıklı çıkar esprisi üzerine işlemekte, bu realite, ister istemez arkadaşlığı araçsal ve maksatlı ilişkilerin adresi haline getirmektedir. Bir başka ifade ile arkadaşlığın doğasında yer alan samimiyet, diğergamlık, tabiilik ve spontanelik gibi hasletlerin bu yeni dönemin ruhuna uygun olarak maksatlı ve ticari bir takım anlamlara doğru evrildiği gözlenmektedir. 
Günümüzde, modernite, küreselleşme, endüstrileşme, kentleşme, teknoradikal gelişmeler vs. bireyci, rasyonel, narsist, özçıkar güdümlü, hesapçı kişilikler ürettiğinden bu kişilik yapıları toplumsal kaynaşma, grupsal süreklilik ve sosyal biraradalık için bir tehlike ve tehdit oluşturmaktadır. Bireyci ya da rasyonel/hesapçı tasarruflar, sosyal yaşam için duygusal ve ruhsal bağlllığı zayıflatıcı, özgeci ve özverili ilişki formlarını öldürücü bir tesire sahiptir. Bu bağlamda belki de en fazla zarar gören sosyal ilişki kalıplarından biri arkadaşlıktır. Arkadaşlık eski ve kadim bir bağllıı türü olmakla birlikte bugün ne yazık ki, değişimin ruhuna uygun şekilde anlam ve işlevsel deformasyon yaşamaktadır.

Toplumsal yapı ve kurumlar da, zaman içerisinde değişime uğrar. 19. Yüzyılda endüstrileşmenin etkisiyle sosyal, ekonomik ve kültürel (özellikle aile) kurumlarda büyük değişimler yaşandı. Sanayi öncesinde çalışma birimi aileydi. Ailede, mal üretimi, yiyecek hazırlama, çocuk bakımı, hasta bakımı, ticaret, sosyalleşme ve gün boyu sıra ile dinlenme gerçekleşirdi. Çalışma rolleri yaş ve cinsiyete göre yapılırdı. Esaslı bir kültürel değişim eşzamanlı olarak kurumsal değişime bağlıdır. Modern ABD'de samimi arkadaşlığın yükselişi incelendiğinde, bireyciliğin yayılması ve sosyal kurumlarda yaşanan değişimlerin arkadaşlığın doğasını etkilediği görülmüştür. Genellikle bireycilikle ilişkilendirdiğimiz değişimler, piyasa ekonomisinin gelişimi ve demokratik politikalara çok şey borçludur. Rekabetçi bir pazarda kendi işinde yasal yetkiye sahip kimse olarak ve liberal siyasette bir vatandaş olarak kattlımcı, bireyciliğin yayılmasının en önemli göstergesidir. Çoğunluğa göre, bu bireyci sosyal roller, akrabanın fonksiyonel önemini ve hane reisinin yetkisini aşındırmakta ve aile hayatını etkilemektedir. Netice itibari ile erkek ve kadın eşlerini seçmede özgürdür ve sevgi için evli kalırlar; özgür seçim ve sevgi, evliliği daha eşitlikçi, hale getirmektedir. Bireycilik, ekonomi, politika ve ailede kültürel ethos haline gelmektedir (Oliker, 1998, s.20-22).

Bireyci roller, aile ve akrabayı zayıflatırken özgür bireyin özgür seçimi arkadaşlığın önemini ve etkisini arttırmaktadır. Diğer taraftan sosyal değişmeye bağlı olarak artan bireyselleşme aile bağlarını zayıflattığı gibi, arkadaşlık bağlarının gücünü de azaltması söz konusudur. Özellikle sosyal ve ekonomik oluşumlardaki baskın değişiklikler tarihsel olarak arkadaşlık formlarını değiştirmiştir. Farklı bir ifade ile arkadaşlar arasında ortaya çıkan yükümlülük ve dayanışmanın doğası, diğer topluluk ağları ve bireysel zorunluluklar tarafından etkilenmektedir. Sınıf, etnik köken, cinsiyet, akrabalık, 
kast, yaş ne olursa olsun diğer sosyal bölünmeler özgürlükleri etkileyecektir (Allan, 1998, s.71).

Çalışma arkadaşlık ilişkilerinde yaşanan değişimleri ortaya koymayı amaçlamaktadır. Öncelikli olarak, sosyal değişme ve arkadaşlık ilişkilerine olan yansıması ele alınmakta, ardından, araştırmanın yöntemi ile ilgili bilgiler verilmektedir. Uygulama kısmında, araştırmada elde edilen bulgular tematik olarak tasnif edilerek yorumlanmaktadır.

\section{Sosyal Değişme Bağlamında Arkadaşlık}

Toplumsal ilişkilerdeki değişim arkadaşlık ilişkilerine de yansımaktadır. Günümüzde toplumsal, ekonomik ve siyasal değişme dünyanın her yerinde ar$\tan$ bir hızla devam etmektedir. Sosyolojideki gelişmelere rağmen toplumsal değişimin doğası, hızı, ayrıntılı ilişkileri tam olarak çözümlenememiştir. Değişme olgusu, sosyolojinin yan sıra ekonomi, siyaset, sosyal psikoloji gibi toplum bilimlerinin diğer disiplinleri tarafından derinlemesine araştırılmaktadır. Değişimin tanımlanması ve açıklanması sosyal bilimcilere her zaman problem oluşturmuştur (Özer, 2003, s.563).

Farklı sosyolojik gelenekler sosyal değişmeyi farklı şekillerde tanımlasalar da toplumsal değişmenin bir sosyal yapı içinde gerçekleştiği konusunda bir uzlaşma vardır. Her yapının farklı unsur ve işlevlerinin olmasının yanında sosyal yapının da kültürel semboller, davranış kalıpları, sosyal örgütlenme ve değer sistemi gibi çeşitli unsur ve işlevleri söz konusudur. Bunlardan birinde veya birkaçında gerçekleşen farklılaşmaların toplumsal yapıya etki etmesi değişimdir (Sunar, 2016, s.2).

Fromm'a göre, yasal düzenlemeler ve devrimler insanların değer yargılarını ve karakterini değiştirmeden, insanlarda yeni bilinç ve inanç oluşturmadan başarıya ulaşamayacaklar. Sosyal değişmenin iki boyutundan söz edilebilir: ilki insan karakterlerinde değişiklik yapmak, ikincisi ise toplumda yasal ve kurumsal düzenlemelere gitmektir. Bunlardan birisi ihmal edildiği takdirde istenen sosyal değişme tamamlanamayacaktır. Sosyal değişmenin sağlanması için salt sosyo-ekonomik değişiklikler yeterli olmadığı gibi, yalnızca insan karakterini, bilincini, değer yargılarını değiştirmek de yeterli değildir (Fromm'dan Akt. Özyurt, 2016, s.165). Görüldüğü üzere sosyal değişme, insan karakteri ve sosyal yapı üzerinde etki bırakarak buralarda değişimler yaşanmasına neden olmaktadır. 
Giddens tarih boyunca toplumsal değişmeyi etkileyen faktörleri fiziksel çevre, kültürel etkenler ve siyasal örgütlenme olarak sıralarken modern dönem için ise fiziksel çevreyi ekonomik etkileri bünyesine toplayarak açıklar. Modern dönemdeki toplumsal değişim süreçlerini etkileyen kültürel etkenler olarak bilimin gelişimi, düşüncenin laikleşmesi, modern bakış açısının eleştirel ve yenilikçi olması sayılabilir. Ekonomik etkenlerin başında sanayi kapitalizminin etkisi gelir. Kapitalizm, üretimin sürekli büyümesi ile servet birikiminin artmasına sebep olmaktadır. Modern dönemdeki değişmeyi etkileyen üçüncü önemli etki siyasal gelişmelerden oluşmaktadır. Ülkeler arasında güç artırımı, servet büyütme ve askeri üstünlük sağlama mücadeleleri son iki ya da üç yüzyıl boyunca değişimin enerjik bir kaynağı olmuştur (2012: 79-83). Toplumsal değişmenin bu etkileri toplumsal yapıda ve toplumsal ilişkilerde değişime neden olmaktadır.

Toplumlar geleneksel ve tutucu olsalar da, her toplum ve kültür sürekli değişim içindedir (Fichter, 2006, s.194). Bir toplum geleneksel yapıdan modern bir yapıya dönüşürken sosyal-kültürel bütünleşmenin çerçevesi olan din ve ailenin yanında mahalle de önemini yitirmektedir. Örneğin sokak, köklü bir işlev değişikliğine maruz kalmaktadır. Çünkü bir şehir ne kadar fazla modernleşirse sokaktaki yaşam ve oyun alanları o kadar fazla arabaların hızlı ve etkin bir şekilde işledikleri bir trafik ağına dönüşmektedir. Bu gelişmenin sokak sakinlerinin yaşam kalıpları açısından büyük sonuçları olmaktadır. Sosyolog G.H. Jansen Utrecht'in bir işçi mahallesindeki bir sokaktan hareketle bu gelişmeyi tasvir eder. Sokak altmışlı yıllardan itibaren sosyal ve kültürel entegrasyonun çöküşünü ortaya koyar. Tüm bu yıllar boyunca çok şey değişmiştir. Her şeyi kuşatan altmışlı ve yetmişli yılların yoksulluğu kaybolmuştur, büyük aileler gitmiş,eski ile karşılaştırıldığında sokak terk edilmiş durumdadır. İnsanlar artık yoksul değil, birbirlerine ihtiyaç duymuyor, kapı önünde bulunan arabalar bir bakıma onların bağımsızlığının ve hareket özgürlüğünün kanıtıdır. Ne değiştiğine bakıldığında aile değişiyor, kendi kendine yeterli hale gelip kendi içine kapanıor ve sırtını sokağa dönüyor (Zijderveld, 2007, s.219-220). Bu bağlamda modern hayat, kent hayatını ve buna bağlı olarak sokak hayatını değiştirmektedir. Modernleşmenin yoğunluğu ve hızı arttıkça kent yaşamında değişim ve dönüşüm belirginleşir. Bu değişim insan ilişkilerine de yansımaktadır. 
Modern şehirler ile geleneksel şehirlerarasında gündelik yaşam ve insan ilişkileri açısından farklılıklar aşikârdır. Zira geleneksel şehirlerde insanlar d1şarıda ve sokakta yer alırken modern şehir hayatında, insanlar sokak hayatından uzaklaşmaktadır. Modern yaşamda aile ve birey kendini toplumdan soyutlamaktadır ve sınırlarını belirleyerek bağımsızlığını ilan etmektedir.

Modern hayat, toplumsal ilişkileri etkilediği gibi arkadaşlık bağları ve ilişkilerini de etkilemektedir. Arkadaşlığın yapısında bulunan, sevgi, samimiyet ve fedakarlık bu durumdan etkilenmekte ve arkadaşlık, farklı anlayışa doğru evrilmektedir. Arkadaşlık ilişkilerinde yaşanan değişimlerde samimiyet, diğergamlık, sağlam ve gerçekçi arkadaşlıkların yerini başka türden arkadaşlıkların aldığını söylemek mümkündür. Sahih manadaki arkadaşlıklar yerine gösterişçi, yüzeysel, bencil ve riskli arkadaşlıkların alması söz konusudur.

\section{AraştırmanınYöntemi}

Çalışmanın amacı arkadaşlık ilişkilerinde yaşanan değişimleri ortaya çıkarmaktır. Çalışma, nitel araştırma yöntemi kullanılarak gerçekleştirilmiştir. Görüşmecilerin arkadaşlık deneyimlerini ortaya çıarmak amacıyla yarı yapılandırılmış görüşme tekniği kullanılmıştır. Görüşmecilerin arkadaşlık deneyimleri üzerinden arkadaşlık ilişkileri yorumlanarak arkadaşlık fenomeni açıklanmaya çalışılmıştır. Bu bağlamda çalışmada nitel araştırma yöntemlerinden fenomenolojik yaklaşım benimsenmiştir.

Araştırmanın evreni Mardin kent merkezidir. Araştırma söz konusu yer ile sinırlıdır. Araştırma alanından, maksimum çeşitlilik örneklemesikullanılarak örneklem grubu oluşturulmuştur. Maksimum çeşitlilik örneklemesinin amacı göreli olarak küçük bir örneklem oluşturmak ve bu örneklemde üzerinde odaklanılan konuya taraf olabilecek bireylerin çeşitliliğini maksimum derecede yansıtmaktır. Buradaki amaç, genelleme yapmak için bu çeşitliliği sağlamak değildir. Aksine bu çeşitliliğe göre problemin farklı boyutlarını ortaya koymaktır (Yıldırım ve Şimşek, 2013, s.136-137). Örneklem, uygun ve yeterli katılımı sağlayacak şekilde seçilmiş ve örneklem grubunun olabildiğine çeşitlilik içermesine dikkat edilmiştir. Maksimum çeşitlilik örneklemesinin tercih edildiği bu çalışmada yaş, cinsiyet, medeni durum, meslek, etnik ve dinsel yapılar göz önünde bulundurularak farklı sosyal kesimlerden 40 kişi örneklem grubuna dâhil edilmiştir. 
Örneklem grubunun \% 60'1 erkek, \% 40'1 kadınlardan oluşmaktadır. Kadınların arkadaşlık deneyimleri erkekler kadar aktif ve yoğun olmamasından ve anlatılanların tekrara girmeye başlamasından dolayı görüşülen kadınların sayısı 16'da kalmıştır.Örneklem grubu oluşturulurken yaş faktörü dikkate alınmış ve farklı yaş gruplarının temsil edilmesine özen gösterilmiştir. Örneklem grubunun \% 37,5'i 31-40 yaş aralığında, \% 27,5'i 20-30 yaş aralığında, \% 20'si 51 yaş ve üstünde, \% 15'i 41-50 yaş aralığında bulunmaktadır. Örneklem grubu, ağırlıklı olarak orta yaş grubundan oluşmaktadır. Örneklem grubunun medeni durum itibariyle \%70'i evli, \% 25'i bekâr ve \% 5'i de dul bireylerden oluşmaktadır. Eğitim durumu itibariyle ise örneklem grubunun \% 50'si lisans, \% 20'si ilkokul, \% 15'i lise, \%12,5'i ön lisans ve \% 2,5'i de yüksek lisans mezunudur. Örneklem grubu ağırlıklı olarak yükseköğrenimli (üniversite mezunu) bireylerden oluşmaktadır. Örneklem grubunun mesleki durumuna bakıldığında \% 27,5'i kamu personeli, \% 12,5'i öğretmen/emekli öğretmen, \% 7,5'i öğrenci, \% 5'er uzman/kamuda yönetici, bakır ustası/telkâri ustası, inşaat mühendisi/inşaat teknikeri, sanayide usta/kaynakçı ve ev hanımı olduğu görülmektedir. Örneklem grubunun \% 22,5'ini diğer meslek grubundan oluşmuş olup bunlar ise müşteri temsilcisi, bankacl, kuyumcu, çocuk gelişimcisi, tıbbi sekreter, vaiz, özel sektör, işçi ve eczane teknisyeninden oluşmaktadır.

\section{Araştırma Bulgularının Değerlendirilmesi}

\section{Sahici/Tabii Arkadaşlıktan Yapmacık/Gösteriş̧̧i Arkadaşlığa}

Kent hayatında insan ilişkilerini belirleyen en önemli faktörlerin başında para gelmektedir. Para ilişkisi kent tipi ilişkinin (bilişsel olarak kötü beslenen ilişkinin) önemli bir örneğidir. Niteliği sadece düşmanlığa ve kötülüğe karşı değil, aynı zamanda dostluğa ve sempatiye karşı da korunmalıdır. Yalnızca duygusal tarafsızlık koşulları altında daha doğru bir ifade ile duyguların rahatsız edici etkisi altında olmayan koşullarda doğru bir şekilde uygulanabilir (Bauman, 2016b, s.209). Nesnelerle herhangi bir ilişkiden kaçınmak kişilere herhangi bir genişleme ve tatmin sağlamayacakmış gibi görünürken satın alma eyleminin kendisi bir tatmin sağlar. Çünkü nesneler paraya mutlak anlamda itaat eder. Para ve para değerleri olarak nesneler tamamen kişinin dürtülerini takip ettiği için sadece fiili mülk sahipliğiyle sağlanacak farklı bir 
hâkimiyet sembolüyle tatmin olur. Örneğin bohem bir gruba mensup bir İngiliz' in hayatta en zevk aldığı şey en çılgın partilere sponsorluk etmekten ibarettir. Zira kendisi bu partilere katılmamaktadır, fakat katılanların masrafını karşılar. Bu, sahip olmanın ve hazzın bir evresi olan savurganlığı göstermektedir (Simmel, 2014, s.314).

Nesnelere sahip olma ve sahip olunanları gösterme, arkadaşlık ilişkilerini etkilemektedir. İnsanların ekonomik anlamdaki gelişimleri hayatlarına ve ilişkilerine yansımaktadır. Maddi imkânlar hayatı kolaylaştırırken bazı sorunları da ortaya çıkarmaktadır. Bir görüşmeci bu nedenle arkadaşlığın istenilen düzeyde olmadığına dikkati çekmekte:

- "Arkadaşlık şu an iyi bir yerde değil. Eskiden çok iyiydi. Ekonomik rahatlık, para, şöhret bunlar arkadaşlı̆̆m bozulmasinda etkili oluyor. İnsanlar daha rahat oldu ama gönlü rahat değil ulaşım çok rahat ve güzel ama zararı çok oluyor. Filankes şöyledir böyledir denilmesi için tuhaf oluyor. Kendinden geçiyor, gösteriş yapacă̆ım diye acayip davranıyor." (40, erkek, Kürt, sanayide usta)

Birey, toplumsal çevrenin ilgisini ve dikkatini bir şekilde üzerine çekmek amacıyla, çevrenin farklılıklara ilişkin duyarlılığından yararlanmaktadır. Sonunda insan, kasıtlı bir şekilde tuhaf olmaya teşvik edilir. Yapmacık tavırlar, ani değişimler vs. gibi metropole özgü aşırılıklara yönelir. Bu tür davranışların anlamının içerikle ilgisi yoktur. "Farklı olma", dikkat çekici bir şekilde diğerleri arasında sivrilme ve böylelikle kendini gösterme amacını taşıyan formlardır (Simmel, 2015, s.107). Bu bağlamda insanlar paraya sahip olma ve bu sahipliği gösterme üzerinden haz elde edebilir. Nitekim, görüşmecilerin bir kısmı, dikkat çekmek için gösterişe meylettiklerini belirtmektedirler. Arkadaşlığın doğasında doğallık vardır. Bu açıdan arkadaşlık ilişkileri, gösteriş ve yapmacıklıkları kaldırmaz. Gösterişe ve yapmacık ile sürdürülen arkadaşlık ancak gösterişçi ya da yapmacık arkadaşlık olur. Bir görüşmeci arkadaşlıkları geçmiş ile mukayese ederek, arkadaşlıklarda artan gösterişin yanında başka özellikler de eklemektedir:

- “Geçmişteki arkadaşlıklar doğal, saf ve yalındı. Bugünkü ise tolere edilecek şekilde oluyor. Gösteriş, riya, özenti, menfaat var, belki çok azında dostluk var. Sebep kültürümüzü bilmememiz, başka kültüre özenme, teknolojiye esir olma, evde bir odada TV'ye hapsolma. Bir insanm farklı şeyleri görmesi farkll, bir noktaya bakıp görmesi farklddır." (58, erkek, Arap, inşaat teknikeri) 
Bireysel özellikler arkadaşlığa anlam yüklemesinden dolayı her bireyin arkadaşlık amacı ve düşüncesi farklı olabilir. Ancak, insanları etkileyen araç ve süreçlerin devreye girmesi ile kültürel olarak tanımlanan arkadaşlıktan farklı bir arkadaşlık ortaya çıkmaktadır. Gümüş paranın yerini alan kâğıt paranın dolaşımı misali, gerçek dostluk yerine yapmacık mimikler, dışarıya karşı oynanan roller dünyada dolaşır (Schopenhauer, 2008a, s.108). Görüşmeci, arkadaşlığın yalın halini gösterişçiliğe, fedakârlık halini menfaate, samimilik halini riyakârlığa bıraktığı düşünmektedir. Bu ayrımlar geleneksel ve modern dönem arkadaşlık ayrımı olarak takdim edilmektedir.

Geçmiş ile kıyas edilen arkadaşlık ilişkilerinde görüşmeciler günümüz arkadaşlıklarında riya, yapmacık ve gösteriş̧̧ilik olduğunu belirtmektedir. Burada ekonomik göstergelerin arkadaşlığın yalın, doğal ve gerçek arkadaşlığı etkilediği düşünülmektedir. Bocock (1997, s.10)'un ifadesiyle tüketim, insanların kim olduklarını ve kim olmak istedikleri ile yakından ilişkilidir. Birey tüketim alışkanlıkları ile kimliğini ortaya koyduğu için tüketim ekonomik olduğu kadar toplumsal ve kültürel göstergedir. İnsanlar tüketirken gösterişçi bir hüviyet kazanmaktadırlar. Bu özellik arkadaşlık ilişkilerine gösterişçi arkadaşlık şeklinde yansımaktadır.

\section{Derin/Samimi Arkadaşlıktan Kısa Vadeli/Yüzeysel Arkadaşlığa}

Modern hayat insanları birbirinden uzaklaştırmakla birlikte birbirlerine karşı kayıtsızlığa neden olmaktadır. Aileyi bile ev içerisinde bir tecride mahkûm eden modern bir hayat söz konusudur. Michael Schluter ve David Lee bugünkü yaşama biçimimiz üzerine bazı iğneleyici yorumlar yapmaktadırlar. Onlara göre, insanlarla karşılaşmamızı engelleyen, onlarla ilişkiyi önleyen her şeyi yapıyoruz, mega-toplumda birbirimizin ayağına basmadan yürüyemiyor, oradan evlerimize giriyor, kapıyı dışarıya kapatıyor daha sonra odamıza girip kapıyı eve kapatıyoruz, ev, aile üyelerinin yan yana ama ayrı yaşayabildiği çok amaçlı bir eğlence merkezi haline geliyoruz. Yorumcuların belirttiği gibi yan yana ama ayrı ayrı. Uzamı paylaşmamıza rağmen düşünce ya da duyguları paylaşmıyoruz. Nereden bakılırsa bakılsın aynı kaderi de paylaşmadıklarının bilincindedir. Bu farkındalık kesinlikle soğukluk ve kayıtsızlığı yayıyor (Bauman, 2014a, s.362). Bu bağlamda insan ilişkileri yüzey- 
selleşirken arkadaşlık bu etkiden nasibini almaktadırlar.Bir görüşmeci, arkadaşlık ilişkilerinin yüzeysel ve kırılgan olduğunu belirtmekte ve bunu modernlikle ilişkilendirmektedir:

- Arkadaşlık ilişkileri geçmişe kıyasla daha yüzeysel, kırılgan ve bireysel çıkarlara dayalı hale gelmiştir. Insanlar hayatın zorluklarma karşı hep beraber mücadele ederek üstesinden gelirlerdi. Modern toplumda her şeyin değişime ŭgradı̆̆ı gibi yaşam tarzlarmm da değişmesi ile insanlar birbirlerine yabancllaşmıştır. Yetmiş haneli bir köyde herkes birbirini tanırken yetmiş dairenin bulunduğu bir apartmanda bırakın herkesin birbirini tanımasını çoğu zaman aynı kattaki kapı komşusunu tanımıyor. Bu arkadaşlık ve komşuluk ilişkilerin geldiği noktayı göstermesi açısından önemlidir. Katı olan her şeyin buharlaşıp yok olduğu modern toplumlarda maalesef arkadaşlık kavramı da nasibini almiştır." (39, erkek, Kürt, memur)

Görüşmeci arkadaşlığın hassas bir süreçten geçtiğini ve kırılganlaştığını savunmaktadır. Bireysel çıkarların, arkadaşlık değerlerinden önce gelmesi arkadaşlı̆̆ı kırılgan hale getirmektedir. Fiziksel yakınlık olmasına rağmen derinlikli bir ilişki gelişmemektedir. Köy ilişkileri ile kent ilişkilerinin karşılaştırmasını yapan görüşmeci bu ilişkiler arasındaki temel farklılığı samimiyet ve yüzeysellik olarak açılamaktadır. Bir görüşmeci samimiyet ve içtenliğin azalmasına vurgu yapmaktadır:

- "Geçmişte saygı vardı, sevgi vardı, muhabbet vardı. Yani samimiyet ve içtenlik vardı. Şimdi kendi çocuğun sana saygı göstermiyor. Düşün çocuğun sana saygı göstermiyorsa arkadaşların sence saygı gösterir mi? Arkadaşlarn modern hayata önem veriyor. Teknoloji de muhabbeti öldürünce arkadaşlar arasinda saygı ve muhabbet kalmadı." (45, erkek, Türk, polis)

Schmid (2018, s.72) arkadaşlığın güzelliği samimiyet olduğunu ifade eder. Görüşmeci geçmiş ile kıyas ettiği bugünkü arkadaşlıkta samimiyet ve saygının azaldığını belirtmektedir. Modernlik, insan hayatını kolaylaştırmaktadır. Bunu teknoloji aracılığı ile gerçekleştirmektedir. Samimiyetin azalması ve içtenliğin yerini yüzeyselliğin almasını teknolojik gelişme ile açıklandığı görülmektedir. Burada teknolojik gelişmelerin arkadaşlar arasındaki sohbeti azaltması ve sohbetteki içtenliği ortadan kaldırması fikri dikkat çekmektedir. Arkadaşlıkların yüzeysel olmasının nedeni de bu fikre dayanmaktadır.

Lynch (2013, s.59) modern dünyada arkadaşlığın özel hayata ilişkin bir olgu olduğunu ifade eder. Arkadaşlık bir karşılıklı bağlılık ilişkisidir ve bireysel seçimin sınırları dâhilindedir. Arkadaşlıklarda birbirine tahammül ve 
katlanmanın olması gerekir. Bazı görüşmeciler, arkadaşlıklarda samimiyetin ve birbirine katlanmanın azalması arkadaşlıkların yüzeyselleşmesine hatta sona ermesine neden olduğunu ifade eder:

- "Eskiden samimiyet vardı şimdi azaldı. Eskiden eylem vardı şimdi söylem. Bana göre siyaset de arkadaşlığı parçaladı. Arkadaşlık politikaya göre değişmeye başladı. Arkadaşlıklar bile kutuplaşmaya başladı. Çok samimi arkadaşı olmasına rağmen siyasi görüş farklılı̆̆ yüzünden arkadaşlı̆̆ıı bitiriyorlar. 25 yil her şeyi paylaşmışlar, kardeş gibi olan arkadaşlar son dönemde siyasi görüşten dolayı birbirlerine selam bile vermiyorlar." (44, erkek, Kürt, özel sektör)

- "Arkadaşliklar yüzeyselleşti. Arkadaşlik artık anlık kuruluyor. Artık arkadaşlıklar kısa süreli, kısa mesafeli oldu. Eskiden arkadaşliklar uzun mesafeliydi. Arkadaşlar bir ömür sürerken şimdi çok az bir zamana sığdırllyyor ve belli bir süre sonra o arkadaşlik bitiyor." (32, kadın, Süryani, öğretmen)

Görüşmeciler arkadaşlıkta samimiliğin azalmasının yanı sıra arkadaşlığın geçici süreliğine kurulduğunu ve siyaset karşısında zayıf kaldığını savunmaktadırlar. Arkadaşlıkta samimiyetin sağlanmaması arkadaşlığın gelişmesine ve derinleşmesine engel olmakta, yüzeysel ve geçici arkadaşlıkların kurulmasına neden olmaktadır. Hayatın her alanında siyaset etkisini hissettirebilmektedir. Siyasi bilincin artması ve siyasi anlaşmazlıklar arkadaşlar arasında siyasi tartışmalara yol açmakta ve bu tartışmalar arkadaşlık bağını zayıflatabilmektedir. Görüşmeci siyasi nedenlerle ciddi ve uzun süreli arkadaşlıkların sona ermesine dikkat çekmektedir. Diğer taraftan olağan bir yüzeyselliğin kabullenişi söz konusudur. Diğer görüşmecinin ifadeleri bu bağlamda ele alındığında arkadaşlıkların kaçınılmaz bir yüzeyselliğe geçtiği fikri ortaya çıkmaktadır.

\section{Diğergam Arkadaşlıktan Egoist/Bencil Arkadaşlığa}

Hem geleneksel dönem hem de modern dönemde arkadaşlıkla ilgili bazı tasavvurlar geçerliliğini korumaktadır. Karşılıklı itimat, karşılıklı anlayış, dertleşme, dürüstlük ve güvenirlik her daim insan ilişkilerinde büyük rol oynar. Arkadaşlı̆̆ın ömür boyu mu, ya da geçici bir süre mi olduğu, ilişki aileden özerk mi yoksa ailenin bir parçası mı sayılmalı gibi sorular ile vurgular farklılaşır. Modern öncesi dönem arkadaşlı̆̆ı kültürel olarak tanımlarken, modern dönem arkadaşlığı bireysel olarak tanımlar. Modern dönemde bireyin, 
arkadaşlı̆̆a ne anlam yüklediklerini, bu ilişkiyi nasıl sürdürmek istediklerini, ilişkide neye önem verdiklerini, birbirlerinde neye kıymet verdiklerini, birbirlerinden ne umduklarını, hassasiyetlerine dair karşılıklı ne gibi bir ikrarda bulunacaklarını kendileri tanımlarlar (Schmid, 2015: 17).

Bazı görüşmeciler arkadaşlık ilişkilerinin değişimini yaş ile açıklarken teknoloji ve maddiyatın da etkilerine değinir:

- Yaştan dolayı arkadaşlık anlayışı değişiyor. Her yaşın kendine göre arkadaşlığı olur. Aile genişlemesi, vakit geçirdiğin kişi sayısının artması arkadaşlı̆̆a ayrılan zamanı azaltıyor. Teknoloji arkadaşlı̆̆ın azalmasına, arkadaşlı̆̆ın değişmesine sebep oluyor. Elbette maddi hırslar arkadaşının arkadaşıyla ilgilenmemesine sebep oluyor. Maddi hırs arkadaşlı̆̆a zarar veriyor." (33, erkek, Kürt, öğretmen)

- "Yaşa bağli olarak arkadaşlık farklilaşıyor. Genel olarak eski saf ve samimi arkadaşlıkların kalmadı̆̆ını düşünüyorum. Menfaat ve çıkar ön planda olmaya başladı̆̆ için arkadaşlık önemi azalıyor. Hem yaşa bağh olarak hem zamana bağhl olarak arkadaşlık ister istemez değişiyor." (38, kadın, Kürt, kamuda yönetici)

Her insanın karakteri bir yaşa uygun görünmektedir. Böylece insan bulunduğu yaşa uygun ve daha yararlı davranır. Kimi insanlar sevecen delikanlılardır ve sonra bundan eser kalmaz; kimileri güçlü, eylemci adamlardır, yaşlılık bunların tüm değerlerini çalar; kimileri de daha yumuşak, diğger bir ifadeyle daha deneyimli ve daha serinkanlı oldukları için, yaşlılıkta en yararlıdırlar. Bunun nedeni, karakterin kendisinde gençliğe, erkekliğe ya da yaşlılığa ilişkin bir şeylerin bulunması, böylelikle o anki yaşın karakterle uyuşması ya da onu dengeleyici etkide bulunmasındandir (Schopanhauer, 2008b: 210). Yaşa bağlı olarak karakterin değişmesi ile birlikte arkadaşlık anlayışında da değişim gerçekleşir. Her yaşın arkadaşlık tecrübesi farklıdır. Bu bağlamda insanların zamanla arkadaşlık algılarında değişim yaşanabilir.Bazı görüşmeciler, geçmiş dönemlerde yaşanılan arkadaşlık ilişkileri üzerinden bugünkü arkadaşlı̆̆

- "Eskiden samimiyet, irfan, kültür, örf, adet vardı. Bugün bunlarn göremezsin. Să̆dan soldan gelenler buraya (Mardin'e) ayak uyduramadılar. Süryani veya Müslüman fark etmez eskiden çok makul insanlardı. Ne konuştuklarmı bilir, lafin nereye gittiğ i bilir. Ticaret ilerideydi. Süryanilerin çok olduğu dönemde Iran, Irak, Suriye ve Lübnan'a badem mahlep gibi ürünler ihraç edilirdi. Dürüst tüccarlar vardı. Insanlar kanaatkârdı. Gelen 1-2 liraya bakmaz, Allaha şükrederdi. Sevecenlerdi, birbirlerini severlerdi. Şimdiki insanlar ile 50-60 yıl önceki insanlar 
bambaşkadır. Eski insanlar medeni, kültürlü, örf ve âdetini seven insanoğlu insandr. Şimdiki menfaatçidir. Eski insanlar Allah'a şükreder ve Allah yoluna gider şimdiki insanlar para yoluna. Varsa yoksa para, başka bir şey yok." (73, erkek, Süryani, telkâri ustasi)

- "Eskiden insanlık arkadaşlık Müslümanlık vardı. Eskiden her şey vardı. Her şeyin de kıymeti vardı. Şimdi bırak arkadaşlık kardeşlik kalmadı. Şimdi kardeşler birbirine düştü. Para ve menfaat insanları değisstirdi. Şimdi kavga var, gürültü var. İnsanlık, Müslümanlık, kardeşlik, arkadaşlık lafta kalıyor." (34, erkek, Kürt, kaynakçı)

Sosyal hayatın birleştirici bağı özel amaçlara dayanan bir birlik özelliği kazandıkça daha ruhsuz hale gelir. Paranın kalpsiz oluşu, sosyal kültürümüze yansır. Para sistemi bireyi geriye dönük olarak kendi üzerinde yoğunlaşmaya yöneltir. Para, bir yandan da aile ve dostluk gibi en yakın bireysel ilişkileri diğer yandan anavatan ya da insanlık gibi en uzak alanları kişisel ve duygusal bağlllık nesneleri olarak terk etmeye sevk eder (Simmel, 2014, s.336-337). Bu bağlamda kültürel hayatımız paranın gücünden etkilenmekte ve para, insanın ilişkilerini belirleyebilmektedir. Görüşmeciler genel olarak insanların değişiminden bahsederek değişimlerin arkadaşlık ilişkilerinde de yaşandığını dile getirmektedir. Geçmiş ile kıyaslandığında insanların genel olarak ciddi bir değişim yaşadığı ifade edilirken görüşmecilerin bu durumdan rahatsızlık duydukları görülmektedir. Bir görüşmeci, Mardin'in farklı kimliklerin hoşgörü içinde bir arada olma özelliğini vurgulamaktadır. Ancak günümüzde örf, adet ve geleneğin aşındığı, günümüz insanlarının "menfaatçi" olduğu ifade edilmektedir.

Günümüz tüketim kültürü ve yaydığı değer ölçüleri, doğal olarak, arkadaşlık ilişkilerini etkilemektedir. Tüketim kültürü, insanların kişilerarası ilişkilerini etkilerken bu etkiden nasibini alan insanlar sosyal ağ bağlamında kendi çevresini etkilemesi söz konusudur. Tüketim, insanların benliğini etkileyecek bir yöntem kullanmaktadır. Ahlaki ilgi ile tüketici ürünler arasında köprü kurulmaktadır. "Ötekine karşı sorumluluk" kavramında kök salan ve gelişen eğilimler, "kişinin kendisine karşı ve kendine ait sorumluluğu" temelinde dönüşüm geçirmektedir. "Bunu hak ettin", "bunu kendine borçlusun”, "kendini biraz şımartmayı hak ediyorsun", bu ve benzeri ahlaki mecburiyetler alanından ödünç alınan veya aşırılan kavramları açığa çıkaran çağrıların, tüketicileri kendine düş̧ünlüğünü meşrulaştırmak amaciyla kullanılmaktadir (Bauman, 2014b, s.103). 
İnsanlar kendi alışkanlıklarından ve tüketimlerinden ödün vermedikleri için çıkarlarını ön planda tutmaktadır. Görüşmeciler çıkar nedeniyle arkadaşlıkta kanaat ve güven kalmadığını ifade etmektedirler:

- "Hayat koşullarn insanları değiştiriyor. Arkadaşlıklarm \% 70-\% 80'i değişmiş. Şimdiki arkadaşliklarm \% 70-\% 80'i menfaate dayanıyor. Eskiden kanaat vardı şimdi menfaat." (59, erkek, Arap, memur)

- "Sadakat kalmadl, çıkar ön plana geldi. Kibir, güven sorunu var. Eski insanlar daha sadakatliydi. Şimdiki insanlar kibirli hale geldi ve menfaatleri ön planda tutuyor. Eskiden güven vardr. Şimdi kimse kimseye güvenmiyor. Bu şartlarda iyi arkadaş bulmak zor. Onun için arkadaşlık anlayışı değişiyor. Insanlar menfaate göre arkadaş oluyor." (36, erkek, Arap, işçi)

Twenge ve Campbell (2015, s.229) yeni maddeciliğin, yapısında narsistik olmayan birçok kimseyi de içine çektiğini söylemektedirler. Micheal Silverstein ile Neil Fiske Tradin Up (Bir üst modeli almak) isimli çalışmalarında "hayatınızı en güzel biçimde yaşamak" ve kendinizi ödüllendirmek düşüncesine giderek daha çok önem verilmesi Amerikalıları eskiden lüks şeylere heves ettiklerinde yaşadıkları suçluluk duygusunu azalttığını tartışır. Reklam sloganları maddeci bir hak iddiacılığını bir erdem olarak teşvik ediyor. Hak iddia eden karakter özelliğini ölçen testteki birçok madde insanlara gerçekte ihtiyaçları olmayan ya da sağlıksız şeyleri almalarını telkin eden o reklamlara korkunç bir şekilde benzemektedir. Tıpkı hak iddiasında bulunan kişilerin, "benim gibi insanlar arada bir fazladan molayı hak ediyorlar" maddesine katılmaları gibi Mcdonald's, Amerikalılara "bugün molayı hak ediyorsunuz" diyor. Yine Loreal saç boyası markası "çünkü ben buna değerim" sloganı ile hak iddiası testinde yer alan, "en iyisini talep ediyorum, çünkü ben buna değerim" maddesine benziyor. Paraya verilen değer aslında çocuklukta başl1yor. Çocukların kullandıkları eşyalarının üzerinde "sıcak para" ve "para içinde yüzüyorum" gibi sloganlar yer alır. Aslında çocuklardan başlayıp her yaş ve cinsiyete yönelik maddeci mesajların yer alması maddeciliği meşrulaştırmaktadır. Bu durum insanlara da yansımaktadır. Görüşmeciler, insanların kendilerini düşündükleri için başkasını düşünme, sadakat ve güven gibi duyguları kaybettiğini savunmaktadır. Tüketim kültürünün yaydığı bilgiler insanları kendi çıarlarını ve hazlarını ön planda tutmasına neden olmaktadır. Kendi çıkar ve hazzını düşünen birey arkadaşlarına güven duymaz ve birbirilerine sadakat göstermezler. 


\section{Güvene Dayalı Arkadaşlıktan Endişeli/Riskli Arkadaşlı̆̆a}

Modern dönem ile birlikte insanlar farklı̈ özellikler elde etmeye başladı. Marcuse (1990, s.11) tek-boyutlu düşünce ve davranış kalıbını elde eden insanı "tek boyutlu insan" olarak ifade eder. Burada, içerikleri nedeniyle yerleşik söylem ve eylem evrenini aşan düşünce, özlem ve hedefler ya püskürtülmekte ya da bu evrenin terimlerine indirgenmektedir. Verili dizgenin ve onun nicel uzamının rasyonelliği tarafından yeniden tanımlanmaktadırlar. Farkında olsun ya da olmasın böyle bir esaret neticesinde insanların düşünce ve algıları değişmekle birlikte herkes birbirine benzemeye başlar. Bunun neticesinde insan bireysel ama tek boyutlu bir varlığa dönüşür. Tek boyutlu varlık aynı zamanda rasyonel bir varlıktır. Aşırı akılcllık kendi içinde irrasyonel bir sürece yol açarak insana dostane olmayan ilişkilere kapı aralamaktadır. Böylelikle insani ilişkiler ve sosyal tercihler standart ve ortalama bir boyut kazanmaktadır (Aytaç, 2005, s.15).Rasyonel insan, duygularından, değerlerinden ve inançlarından sıyrılarak kendini sağlama alan ve riske girmeyen bir durumu benimser. Rasyonel birey, arkadaşına yardım etme ve hemhal olma durumundan uzaklaşır. Bunların yerine birey endişe, kaygı ve risklerden kendini beri tutmayı gaye edinir. Birey, arkadaşı için riske girmek yerine arkadaşlıklardaki risklerden korunma amacıyla arkadaşlı̆̆ın sorumluluğundan kaçnır.Bir görüşmeci teknolojik araçların insanları tekdüze bir hale getirdiğini ve arkadaşlı̆̆ın özelliklerinin değiştiğini ifade etmektedir. Diğer görüşmeci ise teknolojinin bu değişime etkisini vurgulamaktadır:

- "TV, internet, telefon subliminal mesaj veriyor. Insanlar kitleleştiriyor, algılarmı değiş̧tiriyor. Arkadaşlık çok paylaşmaktı, şimdi az paylaşmak var. Eskiden arkadaşlık güzel bir şeydi. Güvenilebilir ilişkiler vardı. Yol arkadaşlığı vardı, beraber yola giderlerdi, yarı yolda bırakma olmazdı. Canı pahasina da olsa bırakmazdr. Arkadaşlıktan uzaklaştığın zaman kendin de uzaklaşırsın. Genelde örf adetler bir bir kayboluyor." (43, erkek, Arap, bakur ustasl)

- "Eskiden arkadaşlık samimiydi, imkânsızlı̆̆a rağmen paylaşımcıydr. Fakat günümüzde arkadaşının en ufak işini yapamayınca ilişkiyi bitirenler oluyor. Teknoloji ile tanışanlar değiş̧ime uğruyor. Arkadaşlık halen var. Ama eskiden daha kaliteli, seviyeli, sağlam ve dürüsttü. Yardımlaşma konusunda bugün arkadaşlık gözünü kaçırarak gözden kaybolmayı tercih ediyor. En önemlisi güven kalmadı. Herkes herkesten korkuyor, çünkü kimse kimseye güvenmiyor." (53, erkek, Arap, memur) 
Görüşmeci teknolojinin bireylerin algılarını değiştirdiğini belirtmektedir. Algıları değişen bireyler birbirine benzemekte ve kitleleşmektedir. Bu açıdan bireyler tek boyutlu insana dönüşmektedir. İnsanı merkeze alması gerekirken, bilim ve teknoloji kendisini merkezde konumlandırır. Teknolojiye göre hareket etmesi, insanların zamanla birbirine benzemesine neden olmaktadır. Bunun neticesinde insanlar asıl hüner ve değerlerinden uzaklaşarak bir değişim yaşanmaktadır. Bu değişim, insanlığın ve arkadaşlı̆̆ın değerlerine yönelik sorunların ortaya çıkmasına neden olmaktadır.Görüşmecilerden bazıları geçmiş dönem arkadaşlıklarının daha samimi olduğunu, günümüz arkadaşlıklarında ise güvenin azaldığını belirtmektedir:

- "Arkadaşlıklarda samimiyet azaldı. Insanlar artık zor samimi oluyor. Eskiden güven vardı. Şimdi güven çok zor bir şey. Nasıl güveneceksin. Eskiden daha çok bir araya gelinir daha çok görüşülürdü. Şimdi görüşmeler de azaldı." (27, kadın, Arap, tıbbi sekreter)

Modern öncesi zamanlarda arkadaşlığın tarz ve biçimi kültürel olarak tanımlanırken modern zamanda arkadaşlar, kendileri için arkadaşlığın ne ifade ettiğini bireysel olarak tanımlama özgürlüğünü kullanırlar (Schmid, 2015: 17). Arkadaşlığı bireysel olarak tanımlama özgürlüğü her birey, kendi dünyasına göre bir arkadaşlık tarzını ve biçimini oluşturur. Modern öncesi dönemde insanların karşılaştıkları ile tanışmama ve arkadaş olmama ihtimali yoktu. Ancak modern zamanda karşılaşmalar dikkate alınmayabilir, tanışıklık ve arkadaşlığa dönüşmeyebilir. Kent bir kimseye sadece yakın çevresinde yaşayanlara değil günlük etkileşim içerisinde karşılaştı̆̆ı herkese karşı kayıtsızlık imkânı sunar (Simmel, 2005, s.28). Goffman bu duruma sivil kayıtsızlık ismini vermektedir. Sivil kayıtsızlık bir şehirde yabancılar arasında yaşamayı mümkün kılan teknikler arasındadır. Burada kişi, bakmıyor, dinlemiyor gibi yapmasıdır ve göz göze gelmekten kaçınır (Bauman, 2016a, s.79).

Gittikçe zorlukların arttı̆̆ bir dünyada mücadele etme zorunluğu ortaya çıkmaktadır. Bu mücadelede arkadaşlar ve dostlar en büyük yardımcı olmasına rağmen zorlukların üstesinden gelme ile ilgili şüpheler var. Bauman (2000, s.64-65) yaşadığımız sıkıntıların üstesinden gelmede arkadaşların ve dostların çaresizliğini vurgular:

- "Hayat kurlgan ve tehlikelerle doluydu; dostluk onu biraz daha katı ve biraz daha emniyetli kulabiliyordu. Bütün arkadaşlar el ele verdiğinde ve husumete hep birlikte karşı koyduklarında, dostlardan herhangi birine yönelik tehditler savuşturulabiliyor, tehlikelerin ölümcüllü̆̆̈̈ biraz olsun azaltılabiliyordu. Oysa, şimdi 
dostlarm oluşturduğu birleşik cephe tehditleri ve tehlikeleri gideremediği gibi, verdikleri acıyı bile azaltamıyor. Açıkçası, farklı türden tehdit ve tehlikeler bunlar - adeta kurbanlarmmn her birini ayrı ayrı, kendine ayırdığ zamanda vuran, verdikleri acmmn tek başına çekilmesi gereken tehdit ve tehlikeler. Günümüzde yaşanan bireysel ıstıraplar eşzamanlı değil; felaket her kapıyı farklı günlerde, farkh saatlerde seçerek çalıyor. Bu ziyaretler arasında bir bağlantı yok gibi. Ve bu felaketler kurbanlarm adlandırabileceği, parmaklarıla işaret edebileceği, karşısında birleşik bir cephe oluşturup onunla savaşabileceği bir düşmanın yaptığı kötülükler değil. Kaderin silleleri, sabit bir adresleri olmayan, mali piyasalar, küresel ticaret koşulları, rekabet gücü, arz-talep gibi tuhaf ve kafa karıştırıcı isimler ardında saklanan gizemli güçler tarafindan indiriliyor. İnsan sık sık yapılan o "küçültme" egzersizlerinden biri yüzünden işini kaybettiyse, bir sabah uyandiğında bin bir zahmetle edindiği becerilerin miadını doldurduğunu, komşularıla, aileyle ya da sevgilisiyle kurduğu ilişkilerin birdenbire parçalandığinı gördüyse dostlar ne yapabilir, ne işe yarayabilir ki?"

Güven duygusunun azalmasına bağlı olarak her insan ile arkadaşlık kurulamamaktadır. Görüşmecilerden elde edilen veriler ışığında insan ilişkilerinde risk oranı artmaktadır. Arkadaşlara güvenin azalması bu ilişkilerdeki risklerin artması ile ilgilidir. Arkadaşlığın zayıflamasına rağmen, bir görüşmeci sahih anlamdaki arkadaşlıkların olabildiğine dönük umudunu korumaktadir:

- "Arkadaşliklar daha kırlgan ve daha sanal hale geldi. Beraberliklere bile arkadaşlik deniliyor. Zorunlu birlikteliklere bile arkadaşlık deniliyor. Arkadaşlık öyle değil tabi ki. Bütün zorluklara rağmen köklü arkadaşlıklar devam ediyor." (37, erkek, Kürt, uzman)

Arkadaşlık, hayatın kırılganlaşmasını ve sanallaşmasını ve bunların sebep olduğu tehlikeleri bertaraf etme gücünden mahrumdur. Hatta bizatihi arkadaşlığın kendisi maruz kaldığı yüzeysellikten ve kırılganlıktan kurtulma mücadelesi vermektedir. Elbette karamsarlıklara rağmen ontolojik olarak kadim arkadaşlıkların az da olsa süregeldiği düşünülmektedir. Kimi zaman zor süreçler sağlam arkadaşlıkları ve dostlukları güçlendirmektedir. 


\section{Herşeye Rağmen Arkadaşlıklar Yaşamaya Devam Ediyor}

20. yüzyılın başlarında insanların geniş bir kısmı, samimi ve duygusal bir arkadaşlığın iyi bir hayatın önemli bir bileşeni olduğunu düşünmeye başlamışlardır. Aile, akraba veya inançtan ziyade arkadaşlık, modernitenin toplumsal tutkalı olmuştur. Arkadaşlık, yönetme, katlanma, tahammül ve hatta dramatik dönüşümlerden zevk alma, yaş ve yaşanılan tecrübe ile bağları güçlendirmeye yardımcı olmaktadır. Özellikle 20. Yüzyılda modern hale gelen milyonlarca insana yardım eden bu arkadaşlık, yenidünyanın şehirlerinde geçerlidir. Göçmenler, gezginler ve diğer katılımcilar (bir yüzyıldaki kitlesel hareketler) az ya da çok akraba ve aileden farklı olarak arkadaşlara dayanmaktadır. Arkadaşlar, sıklıkla modernliğin açmazlarına etkili bir panzehir olmuştur. Arkadaşlık modern kent hayatının kötü yönlerine (yabancılaşma ve yalnızlı̆̆ içeren) karşı koruma sunmaktadır. 20. Yüzyılda değişimin hem olanakları hem de tehlikelerine geniş bir kesim maruz kaldı. Ayrıca, en azından batı toplumlarında farklı şekilde akrabalık, komşuluk ve topluluk ilişkilerinin zayıfladığını ve güven temelli arkadaşlığın geliştiğini görmüşlerdir (Peel, Reed ve Walter, 2009, s.279). Arkadaşlık zamana ve koşula göre değişmekte ve bazen bireye yeni imkânlar açabilmektedir. Modern hayatın ve çağın getirdiği sorunlar ve zorluklarına rağmen eğlence ve boş zaman etkinlikleri bağlamında olumlu gelişmelere yol açmaktadır. Burada arkadaş ve arkadaş ağları bireyin gelişimine katkı sunmaktadır.Bir görüşmeci, arkadaşlık ilişkilerinde yaşanan değişimi normal karşılamakta ve bu duruma olumsuz bir anlam atfetmemektedir:

- "Her şey zaman gerektirdiği gibi yaşanıyor. Bana göre arkadaşlık değişmedi. Eskiden arkadaşlar ile beraber sinemaya giderdik. Şimdi, teknoloji var, sinemada birlikte vakit geçirmek yerine internette birlikte vakit geçiriyoruz." (53, erkek, kuyumcu, Süryani)

Arkadaşlık zamana bağlı olarak değişime uğramaktadır. Ancak bu değişimin, arkadaşlığın ruhuna aykırı olmadığı algısı söz konusu olabilir. Görüşmeci, yaşanılan değişime arkadaşlı̆ıın uyum sağladığını düşünmektedir. Geçmişte yaşanılanların ve paylaşılanların zamana ve teknolojiye bağlı olarak dönüşüme uğradığı, ancak, nihayetinde arkadaşlıktaki birlikteliğin bir şekilde varlığını sürdürdüğü anlaşılmaktadır.

Silver, arkadaşlık ilişkilerinin modern dönem ile birlikte daha nitelikli ve seviyeli hale geldiğini ileri sürer. Arkadaşlık ve diğer sempatik bağlar gittikçe 
daha az güçle de olsa, daha kapsamlı grupları bağlayarak, bireyleri geniş topluma entegre eder. Ticari toplumda kişisel ilişkiler erken tarihsel dönemlerin kalıntıları değildir, aslında onlar sadece "her insan değiş tokuş ederek yaşadığı ya da belki bir nebze bir tüccar olarak yaşadığı" toplumda mümkündür (1990, s.1494). Toplumsal sistem içinde geliştirilen kolektif şuur, sosyal ahlak sistemin kabul edilmesini teşvik eder. Durkheim (2016: 90) "ahlaki hayatın toplumun üyeleri üzerindeki ılımlaştırıc, varlık ve seleksiyon mücadelesinin acımasız eylemlerini yumuşatan ve nötralize eden temel unsurunu dikkate almadığını" ileri sürer. Bağllıı çoğu toplumsal etkinlik biçiminin genel bir özelliği görülmekle birlikte bütün kültürel bağlamlarda karşılaşılabileceği varsayılır. Bağlı kişi, modern biçimde bir ilişkiye içkin gerilimlerin varlığını kabul etmesine rağmen, en azından ortalama düzeyde riski göze almaya istekli -tek ödülün bizatihi ilişkinin sağlayabileceği bir doyum olacağını kabul eden- biridir. Bir dost sırf bu nedenle bağlıdır (Giddens, 2010, s.124). Bu bağlamda arkadaşlık tüm risklere rağmen belirli bir seviyede ve doyumda süregelmektedir. Arkadaşlık ilişkilerinde yaşanan değişimin ve dönüşümün olumlu yönde olduğu görüşünü savunanlar da vardır:

- "Artık daha olgun daha geniş düşünüyoruz. Onun dışında değişim olmadı. Değişim iyi yönde oldu. Illetişim araçlarn sayesinde, teknoloji sayesinde ilişkilerin kopmasın engelliyor, paylaşım ve dayanışma da sürüyor. Olgun, bilgili olunca arkadaşlık daha kaliteli oldu." (23, kadın, Kürt, bankacı)

Genel olarak arkadaşlık, seçici yakınlıklara göre bireyler tarafından özgürce seçilen karşlıklılık, güven ve duyguya dayalı özel bir kişilerarası ilişkidir. Arkadaşlar, değerli bir sosyal ve duygusal sermayeyi temsil eder, bir ağ sağlar, ama aynı zamanda duygusal destek, bilgi, güven, mali destek ve etki gibi kaynakların farklı türlerini sunmaktadırlar (Greco, Holmes ve Jordan, 2013, s.19). Bu destekler, arkadaşlığın gelişimine ve sürdürülebilirliğine katk1 sunmaktadırlar. Görüşmeci iletişim araçlarının ve teknolojinin arkadaşlığı olumlu yönde etkilediğini ve arkadaşların arasında paylaşımların devam ettiğini ileri sürmektedir. Bilgi, insan hayatına yeni bakış açları kazandırır. Öğrenilen bilgiler, hayatı farklı anlamlandırmaya ve yeni hayata yeni açılımlar sağlamaya yol açar. Bu bağlamda bilgili kişilerle yapılan arkadaşlıklardan daha çok istifade edilir.

Esasında, iki farklı süreç muhtemelen aynı zamanda meydana gelmektedir. Bir taraftan arkadaşlar çeşitli sosyal görevleri, yükümlülükleri ve işlevleri 
aile ve akrabadan üstlenmektedir. İkinci süreç, arkadaşlığın anlamı değişmektedir. Düşüncemizde iyi bir arkadaş, yakın bir arkadaş ya da en iyi arkadaşın ne anlama geldiği değişmektedir. Beklentilerimiz ve isteklerimiz gelişmektedir ve arkadaşın akraba gibi daha yakın olup olmayacağı gibi bazı fikirler temelinde ilişkilerimizdeki niteliği yargılamaktayız (Pahl, 2000, s.8). Bu bağlamda arkadaşlığın bu süreç içerisinde değişim geçirmekle birlikte önemini koruduğu ve hatta akraba ve ailenin bazı rollerini üstlendiği iddia edilmektedir. Ancak diğer taraftan arkadaşlığın oldukça olumsuz bir süreçten geçerek günümüz arkadaşlığın niteliğinde olumsuz değişimler yaşandığı iddiası söz konusudur. Digby Anderson (2001: 30) bu savı savunmaktadır: Bugün arkadaşlığın eskiye oranla daha naif ve giderek kısıtlı olduğunu ileri sürmektedir. "Naif" derken daha kırılgan ve zayıf olduğunu "kısıtlı" derken iş gibi temel kurumlara itilmiş ve giderek boş zamana ait olarak görüldügüüü ifade etmektedir. Bu çerçevede arkadaşlığın düşük yoğunluklu ve belli sınırlar içerisinde devam ettiğini söylemek mümkündür.

\section{Sonuç}

Bireyin sosyalleşmesinin önemli araçlarından olan arkadaşlık, bireye kişisel ve sosyal destekler sunmaktadır. Arkadaşlık insanların toplumla bir ağ oluşmasına katkısı olduğu gibi aynı zamanda duygusal yönde insanların gelişmesinde de etkilidir. Toplum içinde soyutlanarak ve yalnız kalarak yaşamayı tercih edenleri hariç tutarsak, arkadaşlık, insanların toplumsal ağa katılımını sağlamaktadır

Arkadaşlık ilişkilerinde bir değişim ve dönüşüm yaşanmaktadır. Bu değişimin ve dönüşümün yönü konusunda iki farklı yaklaşım söz konusudur. Hâkim görüş arkadaşlık ilişkilerinde yaşanan değişimin olumsuz yönde olduğudur. Değişim arkadaşlık ilişkilerini yüzeyselleştirmekte ve geriletmektedir. Geçmiş dönem arkadaşlıkları ile günümüzde yaşanılan arkadaşlıklar karşılaştırılması neticesinde günümüz arkadaşlıklarda samimiyet, güven, doğallık gibi özelliklerin kaybolduğu, bunların yerini menfaat, yüzeysellik ve güvensizliğin aldığı görülmektedir. Sahici arkadaşlıkların azaldığı ve bunun yerine yapmacık ve gösterişçi arkadaşlıkların yaygınlaştı̆̆ı kanaati söz konusudur. Arkadaşlıklarda sahici ve doğal davranmaktan ziyade yapmacık ve gösteriş̧̧i söz ve eylemler tercih edilmektedir. Arkadaşlığın doğasında bulunan fedakârlık ve diğergamlığın ise kaybolduğu düşüncesi ağır basmaktadır. 
Bireyselliğin tasvip ve tavsiye edildiği bir dönemde bencilliğin sıradanlaşması olağandır. Bunun neticesinde diğergam arkadaşlıklar azalmaktadır. Ayrıca insanların birbirlerine güven ile bakmamaları sonucunda arkadaşlıkların risk barındırdığı düşüncesine yöneltmektedir. Bu nedenle güvene dayalı arkadaşlıklar yerini riskli arkadaşlıklara bırakmaktadır. Özellikle ekonomik konuların arkadaşlık ilişkilerinde olumsuz etkisi olduğu düşünülmektedir. Günümüz insan ilişkilerini toplumsal alışveriş kuramına göre değerlendirdiğimizde insanların birbirlerinden faydalanma edimi ve dürtüsü ile hareket etmektedir. Arkadaşlıkların "menfaat"e göre kurulduğu iddiası insanların toplumsal alışverişe göre hareket ettiğini göstermektedir. Karşıdakinden fayda elde edilecek ise ahlaki sorgulama yapılmadan arkadaşlık kurulabilmektedir.

Her arkadaşlık ekonomik beklenti ve kaygılar ile kurulmamaktadır. Arkadaşlık, yaşanan değişim ve dönüşüme rağmen muhtevasında yer alan karşllıklılık, sevgi ve bağlılık geçmişe göre azalmakla birlikte varlığını sürdürmektedir. Bu değerlerin varlık düzeyleri ayrıca kişiden kişiye değişebilmektedir. Burada, özellikle modernleşme ve sanayileşme ile birlikte yaşam kalitesinin iyiye gitmesi gibi insan ilişkilerinde de ileriye dönük bir değişimin yaşandığı düşünülmektedir. İnsanlarda saygı, sevgi, bilgi, empati ve sempatinin oluşması sonucunda arkadaşlık ilişkilerinde de verimli, olgun, seviyeli ve karşılıklı fayda gibi kıstaslarda buluşma olacağı düşünülmektedir.

Sonuç olarak, günümüz arkadaşlık ilişkilerinde bir değişim yaşandığı ortadadır. Bu değişimin yönü tartışmalı olsa da ağırlıklı olarak olumsuz bir yönde olduğu kanaati hâkimdir. Arkadaşlığın samimilik, sahicilik, fedakârlık ve güven esaslı olma gibi temel özellikleri değişime uğramaktadır. Bunların yerine gösterişçi/yapmacık, yüzeysel, bencil ve risk temelli arkadaşlıklar olarak isimlendirilebilecek arkadaşlıklar geçmektedir 


\title{
EXTENDED ABSTRACT
}

\section{Changes In Friendship Relations: The Case Of Mardin}

\author{
Ömer Aytaç - Mehmet Tan \\ Firat University - Siirt University
}

Friendship takes an important place in the social life of the individual throughout life. The social aspect of people leads them to make friends and make new friendships. Being a social entity, people socialize with their friends at different stages of life. Friendships are established throughout life from childhood to old age, and these friendships are of different types. Friendships, which started as playmates in childhood, are maintained in different forms as classmates and schoolmates when they begin their education life. Spatially located campuses allow the formation of relationships such as village, neighborhood friendships or fellow townsman. The relations established during religious and national duties point to different types of friendship. Pilgrimage friendship or military friendship is established here, and friendships are maintained through this reference. Relations that develop over the family are mostly named as family friends. In work life, it is possible to see colleagues and work relationships as reflections of friendship in working life.

Friendship relations change depending on factors such as modernization, technological development and globalization. Modern life is under an intense change / transformation pendulum based on rationality, individualization and speed parameters. This naturally affects all kinds of relationship and interaction processes and transforms the natural and spontaneous structure of life. Friendship, as a type of prime commitment, also changes in this process, its meaning and experience forms differ.

This study focuses on the change in friendship relations in today's society and draws attention to shareholder factors and their transformative power in this change. The study is based on a field study, the qualitative research method is followed and the semi-structured interview form is applied on 40 people selected by the maximum diversity sampling technique. 
It is a relationship that affects individuals in the context of friendship, socialization and social interaction. Friendships are important for people to connect and adapt to the social environment. In the study, the current situation of friendship relations was explained through the experiences of the interviewers, and then the changes in this relationship were classified with a relational approach. When current friendship experiences are examined, it is seen that friendships relations have changed compared to past friendships.

It is obvious that there is change occurs in friendship relations. It is possible to interpret this change in two different ways. The first is the claim that friendship relations have lost their importance with change and that friendship relations have become superficial compared to the past. The second claim is that the importance of friendship has increased due to the loss of family and kinship in the center with increasing individualism in modern societies. When the results of our study are analyzed, it is seen that friendship relationships have lost their importance compared to the past. The causes of change in friendship relationships differ. Especially economic factors stand out. Money and interest relationships cause the change in friendship relations to be negative. The interviewees emphasize economic concerns, but they do not pay much attention to money. The fact that people pay more importance to money or the increased power of money changes their relationship with friends compared to the past. Establishing friendships based on economic expectations and interest causes the formation of disposable friendships. Consuming friendships, which is a different form of consumption, is about the maximum profit achieved. This practicality is also experienced in relations such as the use and disposal of objects that make everyday life, and after earning a profit, friendship is consumed in the context of use-disposal, in other words, it ends. Some of the participants state that friendship relations are becoming more and more fragile. Here, alienation and individualization have an effect on friendship. With the influence of individuality, individuals can be fragile in friendship relations. Individualist understanding prioritizes individual satisfaction. If a friend is not tolerated, a fragile relationship emerges between friends. On the other hand, television, internet and mass media cause people to both become alienated and mass, while making friendships superficial. In today's world, the natural friendship relations of the past with the effect of pretentious and consumption are replaced by the hypotcritical fri- 
endships of wannabe individuals. The appearance of arrogance and self-liking rather than modesty or equality in friendships is an indication that the change of friendship relationships is negative. In addition, it is seen that the number of friendships that should be based on sincerity and trust has decreased compared to the past. While short term friendships increase, long term friendships decrease. Changes in work, education, or location cause shortterm friendships to be established, while preventing previous friendships to continue. With the increase of political awareness, the decrease in tolerance causes politics to be a fragile subject in friendship relations. Political debates seem to harm some friendships. Also, the change in friendship has to do with the course of life. Depending on the age, people undergo physical and mental changes. Changes in the course of life are reflected in friendship relations.

When evaluated in general, it is seen that there is a change in friendship relations. It is obvious that modernization, individualization and technological developments affect friendship relations, and friendship is changing compared to the past. In friendship relationships, there is a change in friendship experiences such as the beginning of the relationship, the establishment of sincerity, the fragility in the relationship and the end of the relationship. It is seen that the time to spend together in friendship relations decreases and friendship is modernized due to technology, individualization and modernization. In addition to these, the idea that there is a decrease in the number of friends, the emotional sharing decreases and the negative characteristics in the human character increase. As a result of outstanding findings; it is stated that there is a radical change in friendship relations and this can be seen in almost all category, social class, gender and professional groups. In friendship relationships, genuine, sincere, altruism and trust-based friendships are replaced by superficial, secondary, pretentious, selfish and risky friendships. However, in spite of the changes in question, it has been seen that friendship regenerates itself depending on social conditions and maintains its strength and necessity.

\section{Kaynakça / References}

Allan, G. (1998). Friendship and private sphere. (R.Adams ve G.Allan Ed.), Placing Friendship in Contex, (s.71-91).Cambridge: Cambridge University Press.

Anderson, D. (2001). Losing friends. London: Social Affairs Unit. 
Aytaç, Ö. (2005). Modern kurumların doğası üzerine eleştirel bir yaklaşım. Amme İdaresi Dergisi, 38(2), 1-23.

Bauman, Z. (2000). Siyaset arayışı. (Çev. T. Birkan), İstanbul: Metis Yayınları.

Bauman, Z. (2014a). Parçalanmış hayat. (Çev. İ. Türkmen), İstanbul: Ayrıntı Yayınları.

Bauman, Z. (2014b). Modernite, kapitalizm, sosyalizm. (Çev. F.D. Ergun), İstanbul: Say Yayınları.

Bauman, Z. (2016a). Sosyolojik düşünmek. (Çev. A. Yılmaz), İstanbul: Ayrıntı Yayınları.

Bauman, Z. (2016b). Postmodern etik, (Çev. A. Türker), İstanbul: Ayrıntı Yayınları. Bocock, R. (1997). Tüketim. (Çev. İ. Kutluk), Ankara: Dost Kitabevi.

Durkheim, E. (2016). Ahlak ve toplum. (Çev. D. Çenesiz), İstanbul: Pinhan Yayıncilik.

Fichter, J. (2006). Sosyoloji nedir. (Çev. N. Çelebi), Ankara: Anı Yayıncılık.

Giddens, A. (2010). Modernite ve bireysel kimlik: Geç modern çă̆da benlik ve toplum.

(Çev. Ü. Tatlıcan), Ankara: Say Yayınları.

Giddens, A. (2012). Sosyoloji. İstanbul: Kırmızı Yayınları.

Greco, S., Holmes, M. ve McKenzie, J. (2013). Friendship and happiness from a sociological perspective.(Ed. M. Demir) Friendship and Happiness, (s.1936)., London: Springer.

Lynch, S. (2013). Dostluk üzerine. (Çev. F. Lekesizalın), İstanbul: Ayrıntı Yayınları. Marcuse, H. (1990). Tek boyutlu insan. (Çev. A. Yardımlı), İstanbul: İdea Yayınları. Oliker, S. J. (1998). The modernisation of friendship: individualism, intimacy, and gender in the nineteenth century. (Ed.R.Adams ve G.Allan) Placing Friendship in Contex, (s.18-42), Cambridge: Cambridge University Press.

Özer, İ (2003). Toplumsal gelişme/değişme. (Ed. İ. Sezal) Sosyolojiye Giriş içinde. (s.559-589), Ankara: Martı Kitap ve Yayınevi,.

Özyurt, C. (2016). Erich Fromm'un insan ve toplum anlayışı. Ankara: Hece Yayınları. Pahl, R. (2000). On friendship. Cambridge: Polity.

Peel, M., Reed, L. ve Walter, J. (2009). The important of friends: the most recent past. (Ed. B. Cine) Friendship: A History içinde (s.317-356.) London: Equinox.

Schmid, W. (2015). Arkadaşlıktaki saadete dair. (Çev. T. Bora), İstanbul: İletişim Yayınlar1.

Schmid, W. (2018). Sakin olmak, yaşlanırken kazandıklarımız. (Çev. T. Bora), İstanbul: İletişim Yayınları. 
Schopenhauer, A. (2008a). Dostluk ve bencillik. (Çev. A. Ö. Savaşçı), (Yay.Haz.Y. Gedik) Dostluk'un Kitabı, (s.107-112.), İstanbul: YGS Yayınları.

Schopenhauer, A. (2008b). Yaşam bilgeliği üzerine aforizmalar. (Çev. M. Tüzel), İstanbul: Türkiye İş Bankası Kültür Yayınları

Silver, A. (1990). Friendship in commercial society: eighteenth-century social theory and modern sociology American Journal of Sociology, 95(6), 1474-1504.

Simmel, G. (2005). Modern kültürde çatışma. (Çev.T. Bora, U. Özmakas, N. Kalaycı ve E. Gen) , İstanbul: İletişim Yayınları.

Simmel, G. (2014). Paranın felsefesi. (Çev. Y. Alogan), İstanbul:İthaki Yayınları.

Simmel, G. (2015). Modern Kültürde Çatışma. (Çev.T. Bora, U.Özmakas, N. Kalaycı ve E. Gen), İstanbul: İletişim Yayınları.

Sunar, L. (2016). Türkiye'de sosyal değiş̧im, İstanbul: Nobel Yayın.

Twenge, J. M. ve Campbell, W. K. (2015). Asrm vebast: Narsisizm illeti. (Çev. Ö. Korkmaz), İstanbul: Kaknüs Yayınları.

Yıldırım, A. ve Şimşek, H. (2013). Sosyal bilimlerde nitel araştırma yöntemleri. Ankara: Seçkin Yayıncılık.

Zijderveld, A. C. (2007). Sahnelik toplum: Sosyolojinin yeniden tanımlanması, (Çev. K. Canatan), İstanbul: Pınar Yayınlar.

\section{Kaynakça Bilgisi / Citation Information}

Aytaç, Ö. ve Tan, M. (2020). Arkadaşlık ilişkilerinde yaşanan değişim: Mardin örneği. OPUS-Uluslararası Toplum Araştırmaları Dergisi, 15(25), 3233-3259. DOI: 10.26466/opus.642395 